\title{
Preventing a Mass Disease: The Case of Gallstones Disease: Role and Competence for Family Physicians
}

\author{
Piero Portincasa ${ }^{1, *}$, Agostino Di Ciaula², Ignazio Grattagliano ${ }^{3}$ \\ 'Department of Biomedical Sciences and Human Oncology, Clinica Medica "A. Murri", University of Bari Medical School, Bari, Italy \\ ${ }^{2}$ Division of Internal Medicine, Hospital of Bisceglie, Bisceglie, Italy \\ ${ }^{3}$ Italian College of General Practitioners, Florence and Bari, Italy
}

Gallstone formation is the result of a complex interaction between genetic and nongenetic factors. We searched and reviewed the available literature to define how the primary prevention of gallstones (cholesterol gallstones in particular) could be applied in general practice. Electronic bibliographical databases were searched. Prospective and retrospective cohort studies and case-controlled studies were analyzed and graded for evidence quality. The epidemiological data confirmed that genetic factors are estimated to account for only approximately $25 \%$ of the overall risk of gallstones, while metabolic/environmental factors are at least partially modifiable in stone-free risk groups, and are thus modifiable by primary prevention measures related to diet, lifestyle, and environmental factors (i.e., rapid weight loss, bariatric surgery, somatostatin or analogues therapy, transient gallbladder stasis, and hormone therapy). There is no specific recommendation for the secondary prevention of recurrent gallstones. Family physicians can contribute to preventing gallstones due to their capability to identify and effectively manage several risk factors discussed in this study. Although further studies are needed to better elucidate the involvement of epigenetic factors that may regulate the effect of environment and lifestyle on gene expression in the primary prevention of gallstone formation, preventive interventions are feasible and advisable in the general practice setting.

Keywords: Bile Acids and Salts; Gallstones; Obesity; Primary Prevention; Risk Factors 


\section{INTRODUCTION}

Gallstone disease (GSD) is one of the most frequent gastro-intestinal disorders in westernized countries, ${ }^{1-3)}$ including Europe. ${ }^{4)}$ There are 3 types of gallstones that develop in the gallbladder and bile ducts, and they are distinguished by their chemical composition: pure cholesterol, pure pigment, or mixed (containing small amounts of bilirubin salts and calcium). In industrialized countries, $75 \%$ of gallstones are composed of cholesterol, approximately $20 \%$ are black pigment stones and $5 \%$ are brown pigment stones (Figure 1). ${ }^{5-8)}$ The costs associated with disease management are high because of the diagnostic and surgical procedures involved. ${ }^{9)}$ Owing to the interplay of metabolic and lifestyle factors in the pathogenesis of GSD, ${ }^{2,10)}$ family physicians (FPs) may play an important role in the prevention of GSD by providing patients
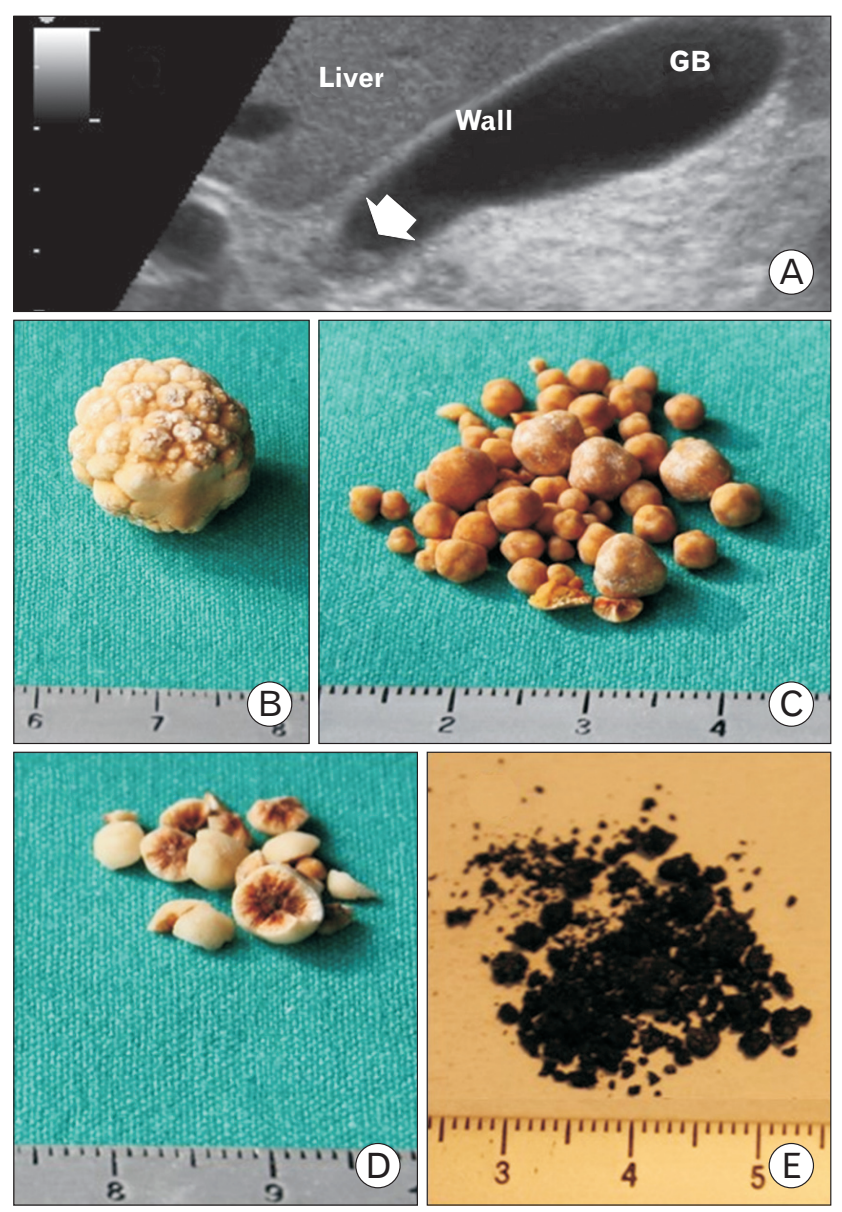

Figure 1. The burden of gallstone disease. (A) Ultrasonographic appearance of a single small gallstone $(0.4 \mathrm{~mm})$ within the GB neck (arrow), seen on a longitudinal transabdominal scan. The hyperechogenic spot is mobile, with decubitus, and is not associated with a posterior acoustic shadow. The GB wall is not thickened (i.e., $\leq 3$ $\mathrm{mm}$ in the fasting state) and the remaining lumen is anechoic. A 1-cm scale is shown on the left. (B) Macroscopic appearance of a solitary pure cholesterol gallstone (approximately $12 \mathrm{~mm}$ ) showing yellowish morular surfaces. (C) Multiple cholesterol gallstones (2-5 mm) with smooth surfaces. (D) Multiple mixed cholesterol gallstones (approximately $5 \mathrm{~mm}$ ) with pigment centers on the cut surfaces. (E) Multiple black pigment gallstones, forming a largely friable sandy powder (approximately $1 \mathrm{~mm}$ ). GB, gallbladder. with education.

In this review, we aimed to identify the essential issues related to the prevention of GSD and to provide FPs with the most current and relevant information for use in their daily clinical practice.

\section{SEARCH METHODOLOGY}

We assessed all literature published from 1974-2015 by searching PubMed (http://www.ncbi.nlm.nih.gov/pubmed). Keywords included the terms 'bile acids,' 'biliary stones,' 'choledocholithiasis,' 'gallbladder,' 'gallstones,' 'prevention,' 'obesity, 'metabolic syndrome,' 'bariatric surgery,' 'very low-calorie diet,' and 'ursodeoxycholic acid or cholesterollowering drugs,' Prospective, retrospective cohort studies, case-controlled studies, and meta-analyses published in the English language in peer-reviewed international journals with adequate impact factors were analyzed. Final selection was based on whether the papers were relevant to clinical practice.

\section{MAIN MESSAGES: THE ESSENTIAL QUESTIONS AND ANSWERS}

\section{Who Are the Subjects at Risk of GSD, and What Are the Most Common Modifiable Factors Involved in the Prevention of GSD?}

Several pathogenic mechanisms have been linked to cholesterol GSD, namely genetic predisposition influencing cholesterol homeostasis (and possibly epigenetic changes), hepatic hypersecretion of cholesterol leading to supersaturated bile, and accelerated precipitation of solid cholesterol crystals in a hypomotile gallbladder, accommodating more mucins. Increased absorption of cholesterol from the intestine is another factor. ${ }^{2)}$ Although a family history of the disease is often suggestive of the role of genetic factors, ${ }^{11)}$ genes are estimated to account for only approximately $25 \%$ of the overall gallstone risk, as suggested by the analysis of the Swedish twin registry. ${ }^{12)}$ In the majority of cases, a genetic background that involves multiple pathways ${ }^{13)}$ determines an individual's predisposition to developing cholesterol gallstones in response to a number of acquired unmodifiable and modifiable environmental factors (Table 1). ${ }^{14)}$ As with other chronic metabolic diseases, GSD is affected by gene-environment interactions and gene expression that is possibly regulated by epigenetic mechanisms. ${ }^{14)}$ Preventive measures are especially effective against cholesterol gallstones because modifiable pathogenic factors are often involved.

\section{1) Obesity and metabolic factors}

The main risk factors for cholesterol gallstones (e.g., obesity, type-2 diabetes, dyslipidemia, and hyperinsulinemia) are the components of metabolic syndrome. ${ }^{2)}$ Increased body mass index is a risk factor for gallstone formation and growth ${ }^{2)}$ and acts as an independent risk factor for symptomatic GSD, particularly in women. ${ }^{15)}$ Waist circumference and triglyceridemia are correlated with GSD. ${ }^{16)}$ Additional obesity-related pro-lithogenic factors include gallbladder stasis, ${ }^{17)}$ insulin resis- 
Table 1. Non-genetic risk factors for gallbladder stones including modifiable, potentially modifiable, and non-modifiable factors

\begin{tabular}{|c|c|c|c|c|}
\hline Factor & Category & Pathogenic mechanism(s) & Stone type & Intervention \\
\hline \multicolumn{5}{|l|}{ Dietary } \\
\hline & $\begin{array}{l}\text { Westernized diet: high-calorie, low-fiber, } \\
\text { high-refined carbohydrate, high-lipid }\end{array}$ & $\begin{array}{l}\text { Hepatic hypersecretion, associated metabolic factors, } \\
\text { gallbladder stasis }\end{array}$ & Cholesterol & Modifiable \\
\hline \multicolumn{5}{|l|}{ Lifestyles } \\
\hline & $\begin{array}{l}\text { Rapid weight loss (bariatric surgery of } \\
\text { morbid obesity), very low calorie diet) }\end{array}$ & $\begin{array}{l}\text { Hypersecretion of biliary mucin, hepatic } \\
\text { hypersecretion, gallbladder stasis }\end{array}$ & Cholesterol & Modifiable \\
\hline & Physical inactivity (especially in men) & $\begin{array}{l}\text { Hepatic hypersecretion, intestinal and gallbladder } \\
\text { hypomotility, decreased bile acid excretion, increased } \\
\text { serum triglycerides, and insulin release }\end{array}$ & Cholesterol & Modifiable \\
\hline & Smoking & Metabolic factors? Others? & Cholesterol, pigment & Modifiable \\
\hline & High alcohol intake & Liver damage, reduced bile acid synthesis & Black pigment & Modifiable \\
\hline \multicolumn{5}{|l|}{ Associated } \\
\hline & Obesity & Hepatic hypersecretion, gallbladder stasis & Cholesterol & Modifiable \\
\hline & Metabolic syndrome, insulin resistance & Obesity, hepatic hypersecretion, dyslipidemia & Cholesterol & Modifiable \\
\hline & Hypertriglyceridemia & $\begin{array}{l}\text { Association with other metabolic abnormalities, } \\
\text { hepatic hypersecretion of cholesterol }\end{array}$ & Cholesterol & Modifiable \\
\hline & $\begin{array}{l}\text { Micronutrients abnormalities: low serum } \\
\text { magnesium }\end{array}$ & $\begin{array}{l}\text { Insulin resistance and deranged serum low density } \\
\text { lipoprotein cholesterol and high density lipoprotein } \\
\text { cholesterol }\end{array}$ & Cholesterol & Modifiable \\
\hline & Vitamin B-12, folic acid deficient diet & Hemolytic anemia & Black pigment & Modifiable \\
\hline & Pregnancy & $\begin{array}{l}\text { Steroid hormones, gallbladder stasis, hepatic } \\
\text { hypersecretion }\end{array}$ & Cholesterol & Potentially modifiable \\
\hline & $\begin{array}{l}\text { Gallbladder stasis (total parenteral nutrition, } \\
\text { total gastrectomy with lymph node dissection, } \\
\text { vagotomy, spinal cord injury, somatostatinoma, } \\
\text { octreotide) }\end{array}$ & $\begin{array}{l}\text { Increased bile concentration and precipitation/ } \\
\text { crystallization of cholesterol }\end{array}$ & Cholesterol & Potentially modifiable \\
\hline & Estrogens and oral contraceptives & Hepatic hypersecretion, gallbladder stasis & Cholesterol & Potentially modifiable \\
\hline & $\begin{array}{l}\text { Drugs: fibrates, octreotide, ceftriaxone, } \\
\text { calcineurin inhibitors (tacrolimus, ciclosporin) }\end{array}$ & $\begin{array}{l}\text { Precipitation in bile (ceftriaxone), hepatic } \\
\text { hypersecretion, inhibition of hepatic bile salt export } \\
\text { pump, bile concentration }\end{array}$ & Cholesterol & Potentially modifiable \\
\hline & Diabetes mellitus* & $\begin{array}{l}\text { Metabolic abnormalities, gallbladder stasis, } \\
\text { autonomic neuropathy }\end{array}$ & Cholesterol & Potentially modifiable \\
\hline \multicolumn{5}{|l|}{ Others } \\
\hline & Female sex & $\begin{array}{l}\text { Pregnancies, steroid hormones, hepatic } \\
\text { hypersecretion }\end{array}$ & Cholesterol & Non-modifiable \\
\hline & Increasing age & Metabolic risks, hemolytic anemia & Cholesterol, pigment & Non-modifiable \\
\hline & Hemolytic anemia, sickle cell disease & $\begin{array}{l}\text { Increased calcium bilirubinate concrement, } \\
\text { gallbladder stasis }\end{array}$ & Black pigment & $\begin{array}{l}\text { Non-modifiable, } \\
\text { potentially modifiable }\end{array}$ \\
\hline & Liver cirrhosis & $\begin{array}{l}\text { Gallbladder stasis, hyperestrogenism, bile salt } \\
\text { malabsorption, increased enterohepatic } \\
\text { circulation of bilirubin }\end{array}$ & $\begin{array}{l}\text { Black pigment, } \\
\text { cholesterol }\end{array}$ & $\begin{array}{l}\text { Non-modifiable, } \\
\text { potentially modifiable }\end{array}$ \\
\hline & Cystic fibrosis & $\begin{array}{l}\text { Increased biliary concentration of conjugated and } \\
\text { unconjugated bilirubin and calcium, increased } \\
\text { enterohepatic circulation of bilirubin }\end{array}$ & Black pigment & $\begin{array}{l}\text { Non-modifiable, } \\
\text { potentially modifiable }\end{array}$ \\
\hline & Crohn's disease, extended ileal resection & $\begin{array}{l}\text { Increased biliary concentration of conjugated and } \\
\text { unconjugated bilirubin and calcium, increased } \\
\text { enterohepatic circulation of bilirubin }\end{array}$ & $\begin{array}{l}\text { Cholesterol, black } \\
\text { pigment }\end{array}$ & $\begin{array}{l}\text { Non-modifiable, } \\
\text { potentially modifiable }\end{array}$ \\
\hline & $\begin{array}{l}\text { Infections (e.g., biliary strictures, duodenal } \\
\text { diverticula, cholangitis, pancreatic insufficiency) } \\
\text { Bile duct (Clonorchis sinensis, Ascaris } \\
\text { lumbricoides, Opistorchis viverrini) } \\
\text { Hepatitis C virus infection }\end{array}$ & $\begin{array}{l}\text { Bacterial } \beta \text {-glucuronization with biotransformation of } \\
\text { conjugated to unconjugated bilirubin, precipitation } \\
\text { together with calcium and long-chain fatty acids }\end{array}$ & $\begin{array}{l}\text { Black pigment, } \\
\text { brown pigment }\end{array}$ & $\begin{array}{l}\text { Non-modifiable, } \\
\text { potentially modifiable }\end{array}$ \\
\hline
\end{tabular}

From Portincasa et al. Lancet 2006;368:230-9, with permission of Lancet. ${ }^{2}$ From Portincasa et al. World J Gastrointest Pharmacol Ther 2012;3:7-20. ${ }^{49}$

${ }^{*}$ Conditions especially associated with gallbladder stasis.

tance, and reduced high density lipoprotein (HDL)-cholesterol. ${ }^{16)}$ Appropriate lifestyle interventions may influence the pathogenesis of cholesterol gallstones, and should focus on maintaining an ideal weight in people with normal weight and weight loss in overweight and obese in- dividuals. ${ }^{15)}$ The key mechanisms regulating this pathogenic process seem to involve gene-environment interactions through epigenetic mechanisms that also occur during the fetal stage and involve factors such as lifestyle, toxic agents, and environmental pollutants. ${ }^{18)}$ 


\section{2) Physical activity}

People should be aware of the importance of performing regular physical activity whenever possible. ${ }^{19)}$ The overall beneficial effect of exercise goes beyond simple protection against gallstone formation. ${ }^{20)} \mathrm{In}$ the Epic-Norfolk prospective cohort study, energy expenditure and cardio-respiratory fitness ${ }^{21)}$ were investigated via questionnaires in 25,639 volunteers (range, 40 to 74 years old). Subjects were monitored over 14 years. After 5 years, 135 cases of symptomatic gallstones (70\% women, $69 \%$ uncomplicated) were observed. After 14 years, 290 cases of symptomatic gallstones ( $68 \%$ women, $54 \%$ complicated) were recorded. The highest level of physical activity was associated with a $70 \%$ decreased risk of symptomatic gallstones in both sexes, with a likely causal effect seen after 5 years. Hyperinsulinemia promotes the hepatic uptake of cholesterol, ${ }^{22)}$ with increased secretion in bile ${ }^{23)}$ and decreased secretion of bile acids ${ }^{24)}$ (leading to supersaturated lithogenic bile). Regular exercise reduces insulin levels, ${ }^{25)}$ insulin resistance, ${ }^{26)}$ triglyceridemia, ${ }^{27)}$ and fatty acid-dependent hypersecretion of gallbladder mucin, ${ }^{28)}$ and increases serum HDL-cholesterol. ${ }^{29)}$ HDL-cholester$\mathrm{ol}$ is the precursor of bile acids ${ }^{30)}$ and is inversely related to gallstone prevalence. ${ }^{31)}$ Finally, physical activity promotes cholecystokinin-dependent gallbladder contraction. ${ }^{32)}$

\section{3) Dietetic factors}

Long-term population-based prospective studies have highlighted difficulties in estimating the quantity and ingestion patterns of nutrients. High-fiber and high-calcium diets reduce biliary hydrophobic bile acids, while a regular eating pattern decreases gallbladder stasis by promoting regular emptying. ${ }^{19)}$ Both aspects play a preventive role against GSD. The likelihood of GSD is increased by westernized diets, including meat intake. ${ }^{33)}$ Fruit and vegetables ${ }^{34)}$ might be protective against GSD, but the data remain controversial. Unsaturated fats ${ }^{35)}$ might protect against GSD. Coffee has been reported to be protective in some ${ }^{36,37)}$ but not all, epidemiological studies. ${ }^{38)}$ Although prospective epidemiological studies reported protective effects of alcohol consumption on gallstone formation, ${ }^{16)}$ and a Danish Mendelian randomization study indicated that patients with symptomatic gallstones consumed less alcohol compared to those with asymptomatic stones, ${ }^{15)}$ the findings are controversial, ${ }^{39)}$ and alcohol consumption cannot be recommended for the prevention of gallstones. Vitamin C supplementation may have a protective effect against GSD. Cholesterol conversion to bile acids requires $7 \alpha$-hydroxylation and appropriate hepatocyte content of vitamin C. ${ }^{40)}$ Vitamin C deficiency might therefore increase the risk of cholesterol gallstone formation. ${ }^{41)}$ Vitamin C supplementation ( $500 \mathrm{mg}$, 4 times/d) was shown to change biliary bile acid composition, increase phospholipids, and prolong the cholesterol crystallization time. ${ }^{42)}$ Observational studies have identified an association between low vitamin C consumption and GSD risk. ${ }^{41)}$ In the EMIL observational population-based study ( $\mathrm{n}=2,129$ subjects; range, 18 to 65 years old), gallstone prevalence was $4.7 \%$ vs. $8.2 \%$ in patients reporting regular use of vitamin $\mathrm{C}(\mathrm{n}=232)$ compared to those who did not report using vitamin C regularly $(\mathrm{n}=1,897){ }^{43)}$

\section{How to Screen People at Risk?}

Abdominal ultrasonography is the most convenient first-line screening test because of its non-invasiveness, low costs, simplicity, and high sensitivity and specificity for detecting the presence of gallstones $(84 \%$ and $99 \%$, respectively). ${ }^{44)}$ The same procedure allows a detailed and simultaneous study of gallbladder morphology (wall thickness, presence of polyps, sludge) and kinetics (fasting and postprandial gallbladder volume with estimation of half-emptying time in response to a standard fatty meal. ${ }^{2,17)}$ Compared to ultrasonography, computed tomography (CT) does not show gallstones if the concretion is isodense with bile. ${ }^{45)} \mathrm{CT}$ with quantitative assessment of stone density may help to select patients for oral bile acid litholysis (i.e., presence of small [ $<5 \mathrm{~mm}$ ], uncalcified [radiotransparent] gallstones). ${ }^{46)}$ For choledocholithiasis, magnetic resonance cholangiopancreatography is the first choice approach because it is noninvasive and has high sensitivity and specificity compared to ultrasonography. ${ }^{47)}$ Endoscopic ultrasonography and endoscopic retrograde cholangiopancreatography have high sensitivity (range, $80 \%$ to $90 \%$ ) and specificity (100\%), but are invasive. ${ }^{47)}$ Furthermore, neither method is free of complications.

\section{Is Any Form of Pharmacological Prevention of Gallstones Effective in the General Population?}

No rationale exists for using pharmacological therapy for preventing GSD. The studies published so far were mainly experimental or incomplete, with a lack of clinical relevance. The investigated agents include the bile acid ursodeoxycholic acid (UDCA), omega-3 fatty acids, $^{48)}$ statins, ${ }^{18)}$ ezetimibe, ${ }^{18,49,50)}$ aspirin, ${ }^{51)}$ and liver nuclear receptor regulators of cholesterol metabolism, i.e., FXR (farnesoid X receptor) agonists. ${ }^{2)}$

\section{Are There Specific Subgroups of Subjects in Which Primary Prevention Is Feasible and Sustainable?}

Approaches to primary and sometime secondary preventive measures are especially effective in the case of cholesterol gallstones (Figure 2).

\section{1) Obese patients undergoing rapid weight loss}

If weight loss is rapid (i.e., over $1.5 \mathrm{~kg} / \mathrm{wk}$ ), ${ }^{52)}$ the risk of gallstones increases significantly, although they tend to be asymptomatic in such cases. This is the case in patients starting very-low-calorie diets (i.e., $<800 \mathrm{kcal} / \mathrm{d}$ ) ${ }^{53)}$ or undergoing bariatric surgery (up to $48 \%$ of patients for weight loss exceeding $25 \%$ of their original weight). ${ }^{53,54)}$ The overall risk decreases when body weight stabilizes after approximately 24 months. ${ }^{53)}$ Weight cycling also represents an independent risk factor for gallstones. ${ }^{55)}$ Excessive de novo biosynthesis of cholesterol and biliary cholesterol excretion are the two main pathogenic factors. ${ }^{56)}$ Some preventive measures are possible during weight-reducing programs.

It is advisable to keep the rate of weight loss to $<1.5 \mathrm{~kg} / \mathrm{wk}^{52,57)}$ The risk of developing symptomatic gallstones decreases if gallbladder motility is improved by appropriate fat content in the diet (at least $7 \mathrm{~g} /$ d) ${ }^{53)}$ UDCA, which is litholytic and hydrophilic, greatly decreases the risk of cholesterol gallstone formation $(<10 \%)$ and of gallstones be- 


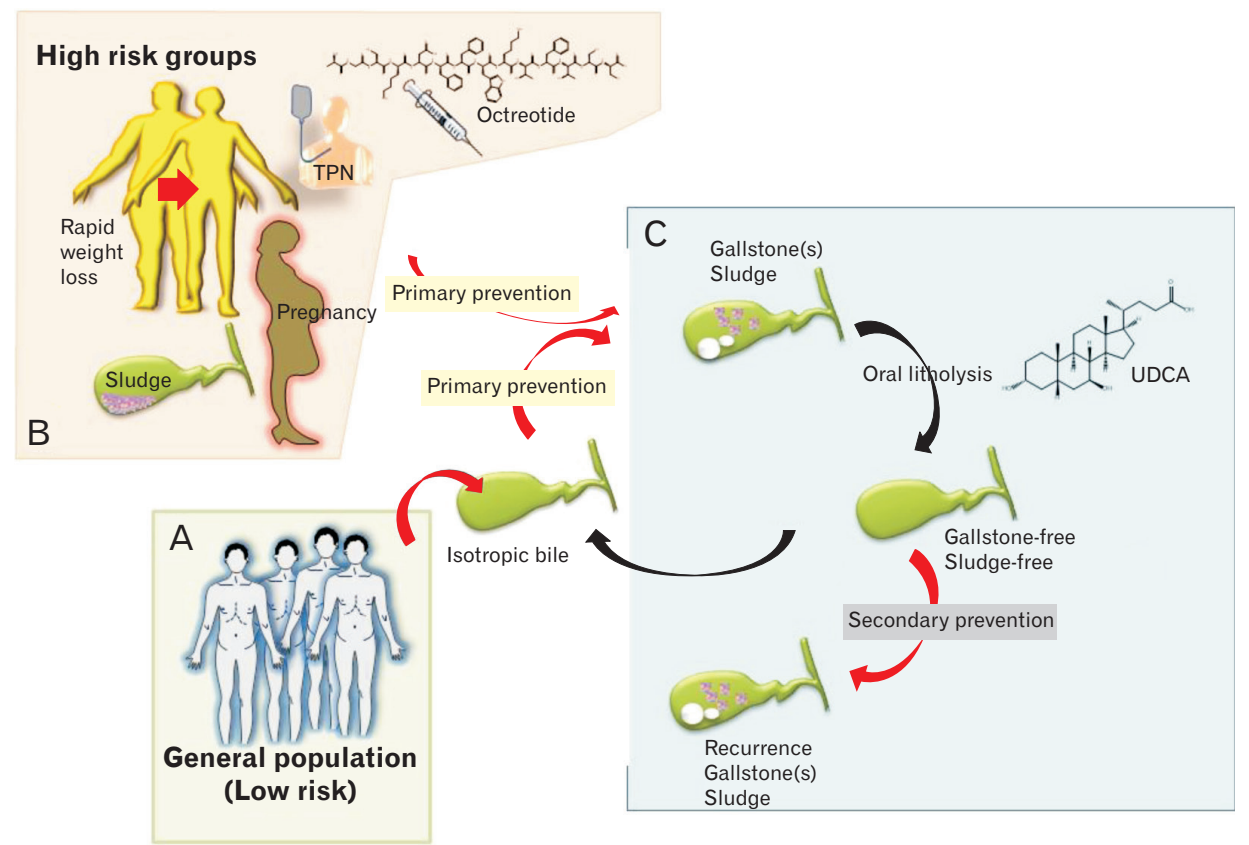

Figure 2. Preventive measures are especially effective in the case of cholesterol gallstones. (A) Primary prevention of gallstones (which contributes to maintaining isotropic bile, meaning free of cholesterol crystals and stones), is already indicated in the general population (at low risk) by generally maintaining healthy lifestyles. (B) Tailored forms of prevention are indicated particularly in high-risk groups (see text and Table 2). Patients with known biliary sludge, pregnant women, patients undergoing rapid weight loss, patients on long-term octreotide, and those receiving long-term total parenteral nutrition are at the highest risk of developing gallstones and subsequent biliary symptoms and/ or gallstone-related complications. Once gallstones/sludge are formed, oral litholysis (by ursodeoxycholic acid) has a very limited role in a small subgroup of symptomatic patients with small, pure cholesterol stones in a functioning gallbladder. (C) If dissolution of concrements is achieved, secondary prevention is indicated in the subgroup of patients at risk of recurrent gallstones/sludge. TPN, total parenteral nutrition; UDCA, ursodeoxycholic acid.

coming symptomatic, ${ }^{58)}$ following rapid weight loss. ${ }^{58,59)}$ A meta-analysis of 5 randomized controlled trials including 521 patients (322 taking UDCA and 199 taking a placebo) concluded that UDCA 300-1,200 $\mathrm{mg} / \mathrm{d}$ effectively prevents gallstone formation after bariatric surgery, ${ }^{59)}$ reducing the incidence from $32 \%$ to $2 \%{ }^{60)}$ with no severe side effects. The beneficial effect of (n-3) polyunsaturated fatty acids (11.3 g/d) on biliary cholesterol nucleation time and crystallization and the prevention of gallstone formation was confirmed in a randomized, doubleblind placebo-UDCA (1,200 mg/d)-controlled trial in obese women on hypocaloric diets $(1,200 \mathrm{kcal} / \mathrm{d}, 20 \%$ energy from fat $){ }^{48)}$ The protective mechanism is probably mediated by the replacement of biliary arachidonate by (n-3) polyunsaturated fatty acids, ${ }^{61)}$ increasing biliary phospholipids, ${ }^{62)}$ and changing intrahepatic cholesterol transportation and the hypersecretion of biliary cholesterol ${ }^{63)}$ Concurrent prophylactic cholecystectomy has previously been recommended based on the assumption that almost $19 \%$ of patients might require a cholecystectomy following bariatric surgery ${ }^{64)}$ The data on this are inconclusive, since up to $97 \%$ of patients remain asymptomatic as confirmed by a recent decision analysis model. ${ }^{65)}$

\section{2) Patients on long-term therapy with somatostatin or analogues}

These patients exhibit biliary lithogenic changes and gastrointestinal motility changes, including delayed intestinal transit and gallbladder stasis. ${ }^{66,67)}$ Prophylactic therapy with UDCA has been suggested for these patients. ${ }^{67-69)}$

\section{3) Patients with marked gallbladder stasis}

Gallbladder stasis and changes in biliary composition are typical in pregnancy ${ }^{70)}$ or during prolonged fasting such as during total parenteral nutrition (TPN). Both sludge and small gallstones might disappear spontaneously in the postpartum period ${ }^{70)}$ and when the oral diet is resumed following TPN. ${ }^{71)}$ Therefore, there is no indication for oral litholysis in either of these conditions.

\section{4) Patients on hormone therapy}

A metanalysis $^{72)}$ showed a significantly increased risk of GSD in women under hormone replacement therapy for the control of menopause symptoms or the prevention of osteoporosis. ${ }^{73)}$ The possibility of any pharmacological preventive approach has not been addressed, and therefore has no rationale as yet.

\section{Are There Any Recommendations for the (Secondary) Prevention of Recurrent Gallstones?}

\section{1) Recurrent gallstones}

The dissolution rate of cholesterol gallstones is $37 \%$ to $60 \%{ }^{74)}$ after 2 years of treatment with UDCA. Recurrence is high following dissolution ( $15 \%$ by 1 year and $45 \%$ by 5 years). ${ }^{75-77)}$ The pharmacological prophylaxis of gallstone recurrence should be restricted to very high-risk subgroups or to patients not fitting the criteria of subsequent cholecystectomy. 


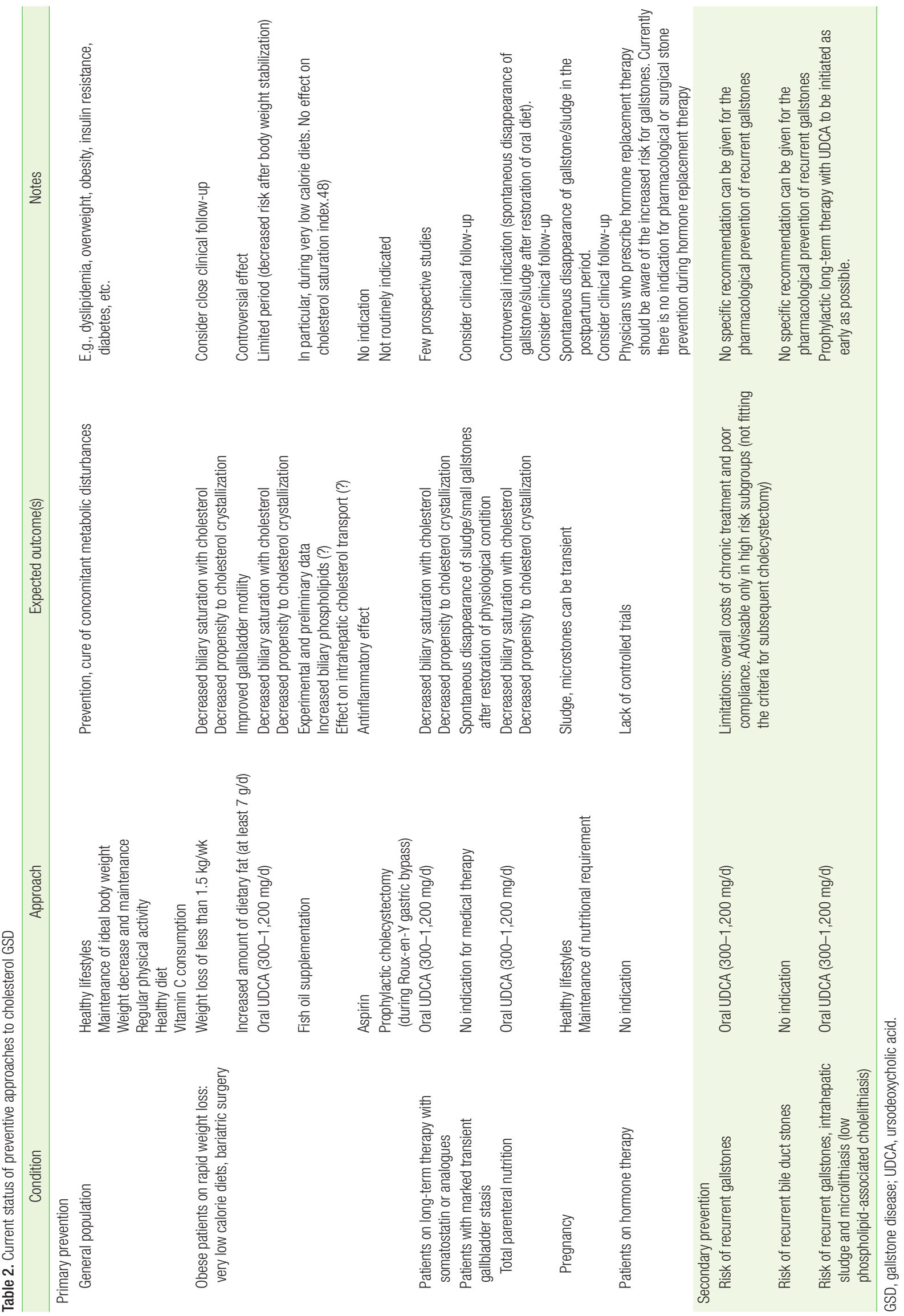




\section{2) Recurrent bile duct stones}

There are no evidence-based prophylactic measures able to prevent the recurrence of bile duct stones.

\section{3) Patients with low phospholipid-associated cholelithiasis}

Heterozygous mutation of the gene 'ABCB4,' encoding the phospholipid-flippase, is a rare form of monogenic predisposition for cholelithiasis associated with low biliary phospholipids and bile salt-mediated damage of the canalicular membrane. In patients with this mutation, gallstones, intrahepatic sludge, and microlithiasis develop before the age of 40 , while biliary symptoms recur after cholecystectomy. ${ }^{78,79)}$ A few studies have suggested that long-term prophylactic therapy with UDCA should be initiated as early as possible. ${ }^{78,79)}$

\section{CONCLUSION}

The epidemiology of GSD (including complications) and the costs associated with its management make all possible primary prevention strategies worthwhile. In general practice, attention should be paid to identifying general and specific modifiable risk factors for GSD and subgroups of patients at risk of GSD. In this setting, educational intervention aiming to prevent GSD should focus on helping patients to have healthy lifestyles, maintain their ideal body weight, partake in regular physical activity, prevent metabolic syndrome, and control all factors influencing glycolipid metabolism and ultimately biliary cholesterol saturation. Pharmacological interventions should be restricted to certain subgroups of patients (Table 2). Further studies will be needed to address the involvement of epigenetic factors regulating gene expression in response to environmental factors in order to identify even better preventive measures.

\section{CONFLICT OF INTEREST}

No potential conflict of interest relevant to this article was reported.

\section{REFERENCES}

1. Attili AF, Capocaccia R, Carulli N, Festi D, Roda E, Barbara L, et al. Factors associated with gallstone disease in the MICOL experience. Multicenter Italian Study on Epidemiology of Cholelithiasis. Hepatology 1997;26:809-18.

2. Portincasa P, Moschetta A, Palasciano G. Cholesterol gallstone disease. Lancet 2006;368:230-9.

3. Everhart JE, Ruhl CE. Burden of digestive diseases in the United States part I: overall and upper gastrointestinal diseases. Gastroenterology 2009;136:376-86.

4. Farthing M, Roberts SE, Samuel DG, Williams JG, Thorne K, MorrisonRees S, et al. Survey of digestive health across Europe: final report. Part 1: the burden of gastrointestinal diseases and the organisation and delivery of gastroenterology services across Europe. United European Gastroenterol J 2014;2:539-43.

5. Diehl AK. Epidemiology and natural history of gallstone disease. Gas- troenterol Clin North Am 1991;20:1-19.

6. Sherlock S, Dooley J. Gallstones and inflammatory gallbladder diseases. In: Sherlock S, Dooley J. Diseases of the liver and biliary system. 11th ed. Oxford: Blackwell Science; 2002. p. 597-628.

7. Trotman BW, Ostrow JD, Soloway RD. Pigment vs cholesterol cholelithiasis: comparison of stone and bile composition. Am J Dig Dis 1974;19:585-90.

8. Attili AF, Carulli N, Roda E, Barbara B, Capocaccia L, Menotti A, et al. Epidemiology of gallstone disease in Italy: prevalence data of the Multicenter Italian Study on Cholelithiasis (M.I.COL.) Am J Epidemiol 1995;141:158-65.

9. Shaffer EA. Epidemiology and risk factors for gallstone disease: has the paradigm changed in the 21st century? Curr Gastroenterol Rep 2005;7: $132-40$.

10. Portincasa P, Wang DQ. Intestinal absorption, hepatic synthesis, and biliary secretion of cholesterol: where are we for cholesterol gallstone formation? Hepatology 2012;55:1313-6.

11. Sarin SK, Negi VS, Dewan R, Sasan S, Saraya A. High familial prevalence of gallstones in the first-degree relatives of gallstone patients. Hepatology 1995;22:138-41.

12. Katsika D, Grjibovski A, Einarsson C, Lammert F, Lichtenstein P, Marschall HU. Genetic and environmental influences on symptomatic gallstone disease: a Swedish study of 43,141 twin pairs. Hepatology 2005;41:1138-43.

13. Wang DQ, Cohen DE, Carey MC. Biliary lipids and cholesterol gallstone disease. J Lipid Res 2009;50 Suppl:S406-11.

14. Di Ciaula A, Wang DQ, Bonfrate L, Portincasa P. Current views on genetics and epigenetics of cholesterol gallstone disease. Cholesterol 2013;2013:298421.

15. Stender S, Nordestgaard BG, Tybjaerg-Hansen A. Elevated body mass index as a causal risk factor for symptomatic gallstone disease: a Mendelian randomization study. Hepatology 2013;58:2133-41.

16. Banim PJ, Luben RN, Bulluck H, Sharp SJ, Wareham NJ, Khaw KT, et al. The aetiology of symptomatic gallstones quantification of the effects of obesity, alcohol and serum lipids on risk. Epidemiological and biomarker data from a UK prospective cohort study (EPIC-Norfolk). Eur J Gastroenterol Hepatol 2011;23:733-40.

17. Di Ciaula A, Wang DQ, Portincasa P. Gallbladder and gastric motility in obese newborns, pre-adolescents and adults. J Gastroenterol Hepatol 2012;27:1298-305.

18. Di Ciaula A, Portincasa P. Fat, epigenome and pancreatic diseases: interplay and common pathways from a toxic and obesogenic environment. Eur J Intern Med 2014;25:865-73.

19. Leitzmann MF, Giovannucci EL, Rimm EB, Stampfer MJ, Spiegelman D, Wing AL, et al. The relation of physical activity to risk for symptomatic gallstone disease in men. Ann Intern Med 1998;128:417-25.

20. World Health Organization. Global recommendations on physical activity for health. Geneva: World Health Organization; 2010.

21. Banim PJ, Luben RN, Wareham NJ, Sharp SJ, Khaw KT, Hart AR. Physical activity reduces the risk of symptomatic gallstones: a prospective cohort study. Eur J Gastroenterol Hepatol 2010;22:983-8.

22. Chait A, Bierman EL, Albers JJ. Low-density lipoprotein receptor activity in cultured human skin fibroblasts: mechanism of insulin-induced stimulation. J Clin Invest 1979;64:1309-19.

23. Nepokroeff CM, Lakshmanan MR, Ness GC, Dugan RE, Porter JW. 
Regulation of the diurnal rhythm of rat liver beta-hydroxy-beta-methylglutaryl coenzmye A reductase activity by insulin, glucagon, cyclic AMP and hydrocortisone. Arch Biochem Biophys 1974;160:387-96.

24. Subbiah MT, Yunker RL. Cholesterol 7 alpha-hydroxylase of rat liver: an insulin sensitive enzyme. Biochem Biophys Res Commun 1984;124: 896-902.

25. Kirwan JP, Kohrt WM, Wojta DM, Bourey RE, Holloszy JO. Endurance exercise training reduces glucose-stimulated insulin levels in 60- to 70-year-old men and women. J Gerontol 1993;48:M84-90.

26. Seals DR, Hagberg JM, Hurley BF, Ehsani AA, Holloszy JO. Effects of endurance training on glucose tolerance and plasma lipid levels in older men and women. JAMA 1984;252:645-9.

27. Tran ZV, Weltman A, Glass GV, Mood DP. The effects of exercise on blood lipids and lipoproteins: a meta-analysis of studies. Med Sci Sports Exerc 1983;15:393-402.

28. Mingrone G, Greco AV, Finotti E, Passi S. Free fatty acids: a stimulus for mucin hypersecretion in cholesterol gallstone biles. Biochim Biophys Acta 1988;958:52-9.

29. Leon AS, Sanchez OA. Response of blood lipids to exercise training alone or combined with dietary intervention. Med Sci Sports Exerc 2001;33(6 Suppl):S502-15.

30. Halloran LG, Schwartz CC, Vlahcevic ZR, Nisman RM, Swell L. Evidence for high-density lipoprotein-free cholesterol as the primary precursor for bile-acid synthesis in man. Surgery 1978;84:1-7.

31. Petitti DB, Friedman GD, Klatsky AL. Association of a history of gallbladder disease with a reduced concentration of high-density-lipoprotein cholesterol. N Engl J Med 1981;304:1396-8.

32. Philipp E, Wilckens T, Friess E, Platte P, Pirke KM. Cholecystokinin, gastrin and stress hormone responses in marathon runners. Peptides 1992;13:125-8.

33. Tsunoda K, Shirai Y, Hatakeyama K. Prevalence of cholesterol gallstones positively correlates with per capita daily calorie intake. Hepatogastroenterology 2004;51:1271-4.

34. Tsai CJ, Leitzmann MF, Willett WC, Giovannucci EL. Fruit and vegetable consumption and risk of cholecystectomy in women. Am J Med 2006;119:760-7.

35. Tsai CJ, Leitzmann MF, Willett WC, Giovannucci EL. The effect of longterm intake of cis unsaturated fats on the risk for gallstone disease in men: a prospective cohort study. Ann Intern Med 2004;141:514-22.

36. Leitzmann MF, Stampfer MJ, Willett WC, Spiegelman D, Colditz GA, Giovannucci EL. Coffee intake is associated with lower risk of symptomatic gallstone disease in women. Gastroenterology 2002;123:182330.

37. Ruhl CE, Everhart JE. Association of coffee consumption with gallbladder disease. Am J Epidemiol 2000;152:1034-8.

38. Walcher T, Haenle MM, Mason RA, Koenig W, Imhof A, Kratzer W, et al. The effect of alcohol, tobacco and caffeine consumption and vegetarian diet on gallstone prevalence. Eur J Gastroenterol Hepatol 2010;22:1345-51.

39. Kratzer W, Mason RA, Kachele V. Prevalence of gallstones in sonographic surveys worldwide. J Clin Ultrasound 1999;27:1-7.

40. Ginter E. Chenodeoxycholic acid, gallstones and vitamin C. N Engl J Med 1976;295:1260-1.

41. Simon JA, Hudes ES. Serum ascorbic acid and gallbladder disease prevalence among US adults: the Third National Health and Nutrition
Examination Survey (NHANES III). Arch Intern Med 2000;160:931-6.

42. Gustafsson U, Wang FH, Axelson M, Kallner A, Sahlin S, Einarsson K. The effect of vitamin $\mathrm{C}$ in high doses on plasma and biliary lipid composition in patients with cholesterol gallstones: prolongation of the nucleation time. Eur J Clin Invest 1997;27:387-91.

43. Walcher T, Haenle MM, Kron M, Hay B, Mason RA, Walcher D, et al. Vitamin C supplement use may protect against gallstones: an observational study on a randomly selected population. BMC Gastroenterol 2009;9:74.

44. Portincasa P, Di Ciaula A, Palmieri V, Vendemiale G, Altomare E, Palasciano G. Sonographic evaluation of gallstone burden in humans. Ital J Gastroenterol 1994;26:141-4.

45. Barakos JA, Ralls PW, Lapin SA, Johnson MB, Radin DR, Colletti PM, et al. Cholelithiasis: evaluation with CT. Radiology 1987;162:415-8.

46. Pereira SP, Veysey MJ, Kennedy C, Hussaini SH, Murphy GM, Dowling RH. Gallstone dissolution with oral bile acid therapy: importance of pretreatment CT scanning and reasons for nonresponse. Dig Dis Sci 1997;42:1775-82.

47. Ledro-Cano D. Suspected choledocholithiasis: endoscopic ultrasound or magnetic resonance cholangio-pancreatography?: a systematic review. Eur J Gastroenterol Hepatol 2007;19:1007-11.

48. Mendez-Sanchez N, Gonzalez V, Aguayo P, Sanchez JM, Tanimoto MA, Elizondo J, et al. Fish oil (n-3) polyunsaturated fatty acids beneficially affect biliary cholesterol nucleation time in obese women losing weight. J Nutr 2001;131:2300-3.

49. Portincasa P, Ciaula AD, Bonfrate L, Wang DQ. Therapy of gallstone disease: what it was, what it is, what it will be. World J Gastrointest Pharmacol Ther 2012;3:7-20.

50. Wang HH, Portincasa P, de Bari O, Liu KJ, Garruti G, NeuschwanderTetri BA, et al. Prevention of cholesterol gallstones by inhibiting hepatic biosynthesis and intestinal absorption of cholesterol. Eur J Clin Invest 2013;43:413-26.

51. Broomfield PH, Chopra R, Sheinbaum RC, Bonorris GG, Silverman A, Schoenfield LJ, et al. Effects of ursodeoxycholic acid and aspirin on the formation of lithogenic bile and gallstones during loss of weight. N Engl J Med 1988;319:1567-72.

52. Weinsier RL, Wilson LJ, Lee J. Medically safe rate of weight loss for the treatment of obesity: a guideline based on risk of gallstone formation. Am J Med 1995;98:115-7.

53. Johansson K, Sundstrom J, Marcus C, Hemmingsson E, Neovius M. Risk of symptomatic gallstones and cholecystectomy after a very-lowcalorie diet or low-calorie diet in a commercial weight loss program: 1-year matched cohort study. Int J Obes (Lond) 2014;38:279-84.

54. Schauer PR, Burguera B, Ikramuddin S, Cottam D, Gourash W, Hamad G, et al. Effect of laparoscopic Roux-en Y gastric bypass on type 2 diabetes mellitus. Ann Surg 2003;238:467-84.

55. Tsai CJ, Leitzmann MF, Willett WC, Giovannucci EL. Weight cycling and risk of gallstone disease in men. Arch Intern Med 2006;166:236974.

56. Li VK, Pulido N, Fajnwaks P, Szomstein S, Rosenthal R, Martinez-Duartez P. Predictors of gallstone formation after bariatric surgery: a multivariate analysis of risk factors comparing gastric bypass, gastric banding, and sleeve gastrectomy. Surg Endosc 2009;23:1640-4.

57. Everhart JE. Contributions of obesity and weight loss to gallstone disease. Ann Intern Med 1993;119:1029-35. 
58. Wudel LJ Jr, Wright JK, Debelak JP, Allos TM, Shyr Y, Chapman WC. Prevention of gallstone formation in morbidly obese patients undergoing rapid weight loss: results of a randomized controlled pilot study. J Surg Res 2002;102:50-6.

59. Uy MC, Talingdan-Te MC, Espinosa WZ, Daez ML, Ong JP. Ursodeoxycholic acid in the prevention of gallstone formation after bariatric surgery: a meta-analysis. Obes Surg 2008;18:1532-8.

60. Sugerman HJ, Brewer WH, Shiffman ML, Brolin RE, Fobi MA, Linner $\mathrm{JH}$, et al. A multicenter, placebo-controlled, randomized, doubleblind, prospective trial of prophylactic ursodiol for the prevention of gallstone formation following gastric-bypass-induced rapid weight loss. Am J Surg 1995;169:91-6.

61. Booker ML, Scott TE, La Morte WW. Effects of dietary fish oil on biliary phospholipids and prostaglandin synthesis in the cholesterol-fed prairie dog. Lipids 1990;25:27-32.

62. Mizuguchi K, Yano T, Kawano H, Abei M, Tanaka N. Preventive effects of eicosapentaenoic acid (EPA) on cholesterol gallstone formation in hamsters. Nihon Yakurigaku Zasshi 1997;110 Suppl 1:50P-55P.

63. Smit MJ, Temmerman AM, Wolters H, Kuipers F, Beynen AC, Vonk RJ. Dietary fish oil-induced changes in intrahepatic cholesterol transport and bile acid synthesis in rats. J Clin Invest 1991;88:943-51.

64. Tarantino I, Warschkow R, Steffen T, Bisang P, Schultes B, Thurnheer $\mathrm{M}$. Is routine cholecystectomy justified in severely obese patients undergoing a laparoscopic Roux-en-Y gastric bypass procedure?: a comparative cohort study. Obes Surg 2011;21:1870-8.

65. Worni M, Guller U, Shah A, Gandhi M, Shah J, Rajgor D, et al. Cholecystectomy concomitant with laparoscopic gastric bypass: a trend analysis of the nationwide inpatient sample from 2001 to 2008. Obes Surg 2012;22:220-9.

66. Moschetta A, Stolk MF, Rehfeld JF, Portincasa P, Slee PH, Koppeschaar HP, et al. Severe impairment of postprandial cholecystokinin release and gall-bladder emptying and high risk of gallstone formation in acromegalic patients during Sandostatin LAR. Aliment Pharmacol Ther 2001;15:181-5.

67. Montini M, Gianola D, Pagani MD, Pedroncelli A, Caldara R, Gherardi F, et al. Cholelithiasis and acromegaly: therapeutic strategies. Clin Endocrinol (Oxf) 1994;40:401-6.

68. Avila NA, Shawker TH, Roach P, Bradford MH, Skarulis MC, Eastman
R. Sonography of gallbladder abnormalities in acromegaly patients following octreotide and ursodiol therapy: incidence and time course. J Clin Ultrasound 1998;26:289-94.

69. Venneman NG, Besselink MG, Keulemans YC, Vanberge-Henegouwen GP, Boermeester MA, Broeders IA, et al. Ursodeoxycholic acid exerts no beneficial effect in patients with symptomatic gallstones awaiting cholecystectomy. Hepatology 2006;43:1276-83.

70. Maringhini A, Ciambra M, Baccelliere P, Raimondo M, Orlando A, Tine F, et al. Biliary sludge and gallstones in pregnancy: incidence, risk factors, and natural history. Ann Intern Med 1993;119:116-20.

71. Marks JW, Stein T, Schoenfield LJ. Natural history and treatment with ursodiol of gallstones formed during rapid loss of weight in man. Dig Dis Sci 1994;39:1981-4.

72. Marjoribanks J, Farquhar C, Roberts H, Lethaby A. Long term hormone therapy for perimenopausal and postmenopausal women. Cochrane Database Syst Rev 2012;(7):CD004143.

73. Cirillo DJ, Wallace RB, Rodabough RJ, Greenland P, LaCroix AZ, Limacher MC, et al. Effect of estrogen therapy on gallbladder disease. JAMA 2005;293:330-9.

74. Rubin RA, Kowalski TE, Khandelwal M, Malet PF. Ursodiol for hepatobiliary disorders. Ann Intern Med 1994;121:207-18.

75. Villanova N, Bazzoli F, Taroni F, Frabboni R, Mazzella G, Festi D, et al. Gallstone recurrence after successful oral bile acid treatment: a 12year follow-up study and evaluation of long-term postdissolution treatment. Gastroenterology 1989;97:726-31.

76. Petroni ML, Jazrawi RP, Pazzi P, Zuin M, Lanzini A, Fracchia M, et al. Risk factors for the development of gallstone recurrence following medical dissolution. The British-Italian Gallstone Study Group. Eur J Gastroenterol Hepatol 2000;12:695-700.

77. Rabenstein T, Radespiel-Troger M, Hopfner L, Benninger J, Farnbacher M, Greess H, et al. Ten years experience with piezoelectric extracorporeal shockwave lithotripsy of gallbladder stones. Eur J Gastroenterol Hepatol 2005;17:629-39.

78. Rosmorduc O, Poupon R. Low phospholipid associated cholelithiasis: association with mutation in the MDR3/ABCB4 gene. Orphanet J Rare Dis 2007;2:29.

79. Marschall HU, Einarsson C. Gallstone disease. J Intern Med 2007;261: $529-42$. 